\title{
India decides on Euthanasia: Is the debate over?
}

\author{
Rateesh Sareen ${ }^{1}$ (i), Akanksha Dutt² \\ ${ }^{1}$ Santokba Durlabhji Memorial Hospital and Research Center, Jaipur, India \\ ${ }^{2}$ Bhagwan Mahaveer Cancer Hospital and Research Center, Jaipur, India \\ Received: 11 April 2019 / Accepted: 09 May 2019
}

\begin{abstract}
Euthanasia is a dilemma due to the presence of more than one course of conduct justified on various grounds. Medical science has devised solutions for battling excruciating pain and agony. The Supreme Court in March 2018 delivered landmark judgment allowing 'living will' where, an adult in his conscious mind, is permitted to refuse medical treatment or voluntarily decide not to take medical treatment to embrace death in a natural way. The judgment gave legal recognition to passive euthanasia in India and robust interpretation of 'right to life' including 'right to die' thereby bringing it within the manifold of article-21 of the constitution of India. The present paper describes the evolution of euthanasia in India contemporary to Dutch law as well as the pros and cons of the landmark judgment in the Aruna Shanbaug case.
\end{abstract}

Keywords: euthanasia, life, will

\section{Introduction}

Euthanasia is an intentional termination of a patient's life by an act or omission of medical care [1]. It can be classified as voluntary or involuntary on the basis of consent and as active or passive depending on the way of termination of life. Active euthanasia involves administration of poisonous substances i.e. an act whereas passive euthanasia encompasses the removal of life support i.e. an omission [2].

Euthanasia is a dilemma due to the presence of more than one course of conduct and has been justified on various grounds. The orthodoxprolife proliferators strongly advocate survival as the sole objective of human existence and oppose euthanasia as they believe that life is a precious gift of God and it is God only who has the right to take it away. Hippocratic oath [3] also puts medical practitioners under ethical obligation for prolongation of life. The common law doctrine empowers individual with the right to autonomy, bodily integrity, and selfdetermination where an adult person of sound mind has voluntary choice to decide what shall be done to his/her body and this right must be respected, accepted irrespective of what others (in this case doctors) may think in the best interest. The care of human life and not its destruction should be the sole legitimate objective of good governance.

The other side of the coin emphasizes on quality of life and believes that when the quality of life falls below the expected level of dignity due to illness, injury, or disability the aggrieved person has the right to die to alleviate from pain as a result of a terminal incurable illness. 
They argue that life should be worth living and when a person is suffering, all things take a back seat except autonomy of patient as such no person can be compelled to enjoy the right to life to his/her disliking or deterrence. A patient who is undergoing suffering due to terminal illness may have unbearable suffering and in such situation patient's autonomy supersedes everything. The state too has limited right to interfere in the affairs of individuals only on the ground of compelling state interest can the state has right to limit individual right of privacy and self-determination provided there is an imminent threat to state or deprivation of third person's right and euthanasia has nothing to do with state or infringement of the third party right hence state intervention is unwarranted. In a world of limited resources and means treating terminally ill patients for long is like a nation's wastage of medical facilities which can be righteously diverted for those who have hope of survival or life.

In a nutshell it's a slippery slope for any rationale pertaining to euthanasia as any attempts to prolong life violates the promise to relieve pain and on the other hand relief of pain by killing violates promise to protect and prolong life in contravention to Hippocratic oath.

Any attempts to legalize euthanasia have to follow guarded approach as legitimizing it might lead to an increase in the casual attitude of health care personnel ultimately leading to private killings for covering up wrong diagnosis and treatments. So far Netherland, Canada, Belgium, Columbia, and Oregon have legalized euthanasia [4].

\section{Dutch Law on Euthanasia}

Under article 293 of Dutch penal code killing of a person is a punishable offense - V degree crime with 12 years of imprisonment [5]. There were a series of judicial decisions that led to the acceptability of euthanasia in Dutch law. Leading cases like Postma case 1973 (termination of life of terminally ill patient), Wertheim case 1982, Schoonhein case or Alkmaar case 1984 (termination of life in patient suffering from chronic illness), Chabots case (termination of life in non-somatic illness), and Prins and Kadijik case (life termination of severely disabled infants in incurable pain) paved way for new law-termination of life on request and assisted suicide act 2001 [5-7]. The act exonerated doctors from the commission of offenses under article 293 and 294 Dutch penal code, if they comply with due care criteria set out in article 2 of the act. Patients suffering from psychological distress as well as chronic and terminal illness and both children and individuals with mental retardation or brain damage qualify for euthanasia. The voluntary consent for euthanasia by an adult mandate's certain requirements like long lasting, well thought consent by the patient, unbearable suffering by the patient, and review by independent experts one among them essentially a psychiatrist. The multidisciplinary review committee to control illegitimate termination of life is one of the unique striking features of the Dutch system. It also requires doctors to report such cases as euthanasia or physician-assisted suicide to the concerned authorities and are not registered as natural deaths.

\section{Indian Scenario Pre-Aruna Ramchandra Shanbaug Judgment}

The constitution of India under article 21 empowers citizens to enjoy right to life and personal liberty bringing within its ambit the right to privacy, right of self-determination, and right of autonomy [8]. The right to die is negative right of right to life and has been the point of debate since decades in Indian judiciary. The legal impediments in recognition of the right to die are sections 309 IPC (Indian Penal Code) and 306 IPC containing penal provisions for attempt and abetment to suicide respectively [9].

Maruti Sripathi Dubal v. State of Maharashtra [10] was the first case where a constable with psychiatric illness tried to commit suicide and subsequently was tried under section 309 IPC. This case brought in light the issue of the constitutional validity of section 309 IPC. It was argued on behalf of the petitioner that committing suicide on account of mental illness should not be punishable as it serves no purpose but only adds to the agony of a failed suicide attempt. Efforts must be made for rehabilitation and psychiatric treatment of such persons. Every fundamental right has both positive and negative aspects and negative aspect of article 21 proclaims right to die, hence section 309 IPC violates article 21 of the constitution.

The next case to follow was that of Rathinam and Nagbhushan Patnaik v. Union of India [11] where the apex court held that section 309 IPC violated article 21. Court went on to the extent of saying that section 309 IPC was a cruel, irrational provision that needs to be effaced from statute books to humanize penal laws and as the act is not against any religion, morality, and public policy with no beneficence to society the state intervention on personal liberty is uncalled for. Hence 309 IPC was not held in line with article 21 of the constitution.

The constitutional validity of section 309 was again in question in case of Gian Kaur v. State of Punjab [12]. Gian Kaur and her husband were convicted by the trial court under 306 IPC of abetting suicide of Kulwant Kaur. The appellant seek relief as the constitutional validity of sec 309 IPC was questionable so was the validity of sec 306 IPC. The court drew a distinction between natural and unnatural extinction of life. Right to die with dignity at the end of natural life should not be confused with the right to die an unnatural death curtailing the natural span of life. Suicide is unnatural extinction of life; a natural positive right cannot go with the unnatural negative right. Hence constitutional validity of sec 309 IPC was upheld and it does not violate article 21 . Those who are terminally ill or in the persistent vegetative state come under the ambit of right to die with dignity, the process of death has already started in such individuals and there is no question of unnatural 
termination, therefore, termination of life can be permitted. Hence sec 309 IPC was treated as valid and not violating article 21- a positive right which provided for the right to live and did not support suicide.

\section{Post-Aruna Ramchandra Shanbaug Judgment}

The apex court in Aruna Shahbang case undertook request under article 32 of constitution filed by Pinki Virani a social activist on behalf of Aruna Shanbaug, a patient in a persistent vegetative state for 37 years in KEM Hospital Mumbai, for withdrawal of artificial feeding. The supreme court sought opinion from KEM hospital staff who was taking care of Aruna as the staff declined for withdrawal of artificial feed, the apex court declined the request but at the same time did an in-depth study of passive euthanasia and issued guidelines which one and shall be in force until central and state government draft rules pertaining to termination of life. The court insisted that for passive euthanasia request must be approved by high court since there is a possibility of mischief by relatives and friends for interior motives. On March 9, 2018, for recognition of 'right to die' with dignity the apex court's five judges constitutional bench in supreme court pronounced it is a judgment granting for the first time in India the legal recognition of 'advanced medical directives' or 'living will'. It refers to the patient's decision communicated in advance on withdrawal of life-saving treatment which should be respected by treating doctors and hospitals. The judgment has a major impact on the ongoing debate on euthanasia in India as it gives legal recognition to passive euthanasia in India and acknowledges robust interpretation of 'right to life' including 'right to die' with dignity thereby bringing it within the manifold of article 21 of the constitution of India.

The judgment goes on to argue the streamlining the process of dying in cases of terminal illness or permanent vegetative state with no hope of recovery. The failure to recognize advanced medical directives may amount to a denial of these rights. It deliberated on a misreading of Gian Kaur judgment and affirmed unambiguously the right to refuse life support intervention as a fundamental right.

The perusal of apex court's judgment March 2018 has laid down detailed procedure with elaboration with regard to advance medical directives on the part of an individual indicating and expressing his consent in writing relating to the circumstances in which withholding or withdrawal of medical treatment can be resorted to. The apex court has elaborated the following:

- Who can execute the advance directive and how?

- What should it contain?

- How should it be recorded and prescribed?

-When and by whom can it be given effect?

- What if permission is refused by the medical board?

- Revocation or inapplicability of advance directive?

The detailed study of the aforesaid tenets manifests that the procedure prescribed is quite cumbersome, tedious, and not easy to adhere to. For example, the document needs to be signed by the executor in the presence of two attending witness and countersigned by Judicial Magistrate of First class. The Judicial Magistrate shall have to preserve one copy in his office in addition to keeping it in digital format. The Judicial Magistrate has to forward one copy for registry of District Judge for preserving and additionally in digital format. A copy shall be given to the family member of executor and also to a competent member of the local government and also to the family physician.

Similarly, the constitution of hospital medical board consisting of the heads of treating department and at least three experts from the fields of general medicine, cardiology, neurology, nephrology, psychiatry, or oncology with experience in critical care and with overall standing in the medical profession for at least twenty years shall decide as preliminary opinion regarding request of executor.

Further to the opinion of the hospital medical board, the jurisdictional collector shall constitute another medical board. This medical board headed by chief district medical officer of the concerned district and three expert doctors as members having overall standing in medical fields of at least twenty years (who were not members of the previous medical boards of the hospital). Further, if the permission is refused by the medical board the executor or his family members can approach the high court by way of a writ petition under article 226 of the constitution. The high court would, however, be free to constitute an independent committee like the earlier ones. It has been indicated that the high court shall render its decision at the earliest but no definite/specific time frame has been prescribed leaving ample scope for delay in decision whereas the executor shall remain with agony/pain in the hospital leading a painful life and counting his days of life. It is crystal clear that the apex court has discussed the case where the person concerned (executor) is ready to provide advance directive. In India where there are illiterate villagers also, the aforesaid procedure will become only a paper law and cannot be understood, enforced pragmatically.

There is dire need to simplify the procedures so that it should be practical, operational and without many ifs and buts, though the March 2018 order has paved the way for following a new approach to the concept of euthanasia.

For passive euthanasia in India, consent by patient, spouse, and children is sufficient whereas if consented by near relative, friend and/or doctor it requires approval from high court until parliament enacts laws. 
In nutshell, it is good judgment although it failed to draw a distinction between active and passive euthanasia. It also could not address special reforms in the health care system and the prescribed process of the living will is cumbersome with many players in-between. The involvement of nursing staff for feeding was debatable as equated with medical treatment. The decision was correct although it could not be a valid precedent. Though the judgment March 2018 is not a perfect one on the subject, still it is a good beginning to address a new concept which was not touched in the past $[13,14]$.

\section{Conflict of interest}

All authors declare that they have no conflict of interest.

\section{Funding}

There was no funding received for this article.

\section{References}

1. Dillman RJM, Legemaate J. Euthanasia in the Netherlands; the state of the debate. Eur Health Law 1994;1:81-7.

2. Van der Wai G, Dillman RJM. Euthanasia in the Netherlands. BMJ 1994;308:1346-9.

3. Miles SH. The Hippocratic oath and the ethics of medicine. New York: Oxford University Press; 2004.

4. LawTeacher [Internet]. Analysis of euthanasia law in Netherlands and UK. c2003-2019 [cited 25 Jan 2019]. Available from: https://www.lawteacher.net/free-law-essays/human-rights/analysis-of-euthanasia-law-in-Netherlands.php?vref=1.

5. Snijdewind MC, van Tol DG, Onwuteaka-Philipsen BD, Willems DL. Developments in the practice of physician-assisted dying: perceptions of physicians who had experience with complex cases. Journal of Medical Ethics 2018;44:292-296

6. Jochemsen H. Update: the legalization of euthanasia in the Netherlands. Ethics Med 2001;17:7-12.

7. The Dutch Penal Code Act of 1997. No: 287,293,294.

8. The Constitution of India [Internet]; 1950 [cited 24 Jan 2019]. Available from: https://www.refworld.org/docid/3ae6b5e20.html.

9. The Indian Penal Code Act of 1860. No: 45

10. indiankanoon.org [Internet]. Dubal MS vs State of Maharashtra [cited 25 Jan 2019]. Available from: https://indiankanoon.org/doc/490515/.

11. indiankanoon.org [Internet]. Rathinam P vs Union of India [cited 25 Jan 2019]. Available from: https://indiankanoon.org/doc/542988/.

12. indiankanoon.org [Internet]. Kaur G vs The State of Punjab [cited 25 Jan 2019]. Available from: https://indiankanoon.org/doc/217501/.

13. Rajagopal K. SC Constitution Bench holds passive euthanasia, living wills permissible [Internet]. The Hindu; 2018 [cited 24 Jan 2019 ]. Available from: https://www.thehindu.com/news/national/sc-recognises-living-will-by-terminally-ill-patients-for-passive-euthanasia/article22991873.ece.

14. indiankanoon.org [Internet]. Shanbaug AR vs Union of India [cited 25 Jan 2019]. Available from: https://indiankanoon.org/doc/235821/. 